\section{Polyembryony in Undeveloped Monoembryonic Diploid Seeds Crossed with a Citrus Tetraploid}

\author{
I. Oiyama and S. Kobayashi \\ Akitsu Branch, Fruit Tree Research Station, Akitsu, Hiroshima, \\ 729-24 Japan
}

Additional index words. embryogenesis, seed development, polyploid

\begin{abstract}
Some undeveloped seeds from mature Citrus fruit of monoembryonic diploid cultivars crossed with a tetraploid selection were observed to be polyembryonic. The multiple embryos formed a small mass the the micropylar end. Plants regenerated in vitro from the embryos in polyembryonic seeds were triploid and showed identical peroxidase banding patterns on acrylamide gels. These results indicate that the multiple embryos found in the undeveloped seed from monoembryonic diploid $\times$ tetraploid crosses are genetically identical and of zygotic origin.
\end{abstract}

Polyembryony is a common feature in Citrus. Multiple embryos are produced from nucellar cells. However, some cultivars have been reported to produce two or more sexual embryos in one seed (Bacchi, 1943; Cameron and Garber, 1968; Frost, 1926; Ozsan and Cameron, 1963; Parlevliet and Cameron, 1959; Ueno et al., 1967). Sexual polyembryony may be due to multiple fission of the zygotic embryo or the presence of more than one egg in an ovule (Bacchi, 1943). Cameron and Garber (1968) presented cytological evidence that supernumerary sexual embryos could occur by budding from the primary embryo. We describe polyembryony in undeveloped seeds from mature fruit of monoembryonic diploid cultivars crossed with a tetraploid and discuss its origin.

Two monoembryonic diploid cultivars, Clementine mandarin (Citrus clementina Hort. ex Tanaka) and Miyarrchi Iyokan (C. iyo Hort. ex Tanaka) were hand-pollinated with tetraploid 'Kawano Natsudaidai' (C. natsudaidai Hayata) pollen. Hand pollination was carried out immediately following emasculation of flowers, and all the pollinated flowers were covered with bags. Seeds were extracted from mature fruit 7 months after pollination and were classified as well-developed or undeveloped (Fig. .1). Embryo formation in undeveloped seeds was observed under a binocular dissecting microscope.

Most of the seeds produced by each seed parent in the cross with the tetraploid were undeveloped (Table 1). The frequency of normal seed development was greater for 'Miyauchi Iyokan' than for 'Clementine'. The high frequency of undeveloped seeds from $2 \mathrm{x}-4 \mathrm{x}$ crosses, already reported by several workers (Cameron and Soost, 1969; Esen and Soost, .1972, 1973; Oiyama et al., 1981; Tachikawa et al., 1961), has been attributed

Received for publication 4 Nov. 1989. Contribution no. E-124 of the Fruit Tree Res. Sta. The cost of publishing this paper was defrayed in part by the payment of page charges. Under postal regulations, this paper therefore must be hereby marked advertisement solely to indicate this fact. to abortion of triploid embryos at various stages of embryogenesis (Esen and Soost, 1973).

The undeveloped seeds from these crosses were classified as monoembryonic, polyembryonic, or embryoless. The percentage of polyembryonic seeds was higher in the cross using 'Miyauchi Iyokan' as the seed parent (Table 2). The' embryos in polyembryonic seeds formed a small mass at the micropylar end (Fig. 2). These embryos were nearly globular in shape but very dissimilar in size. The number of embryos differed greatly among seeds in each cross. The mean number of embryos per seed was about half as great in 'Clementine' as in 'Miyauchi Iyokan' (Table 3).

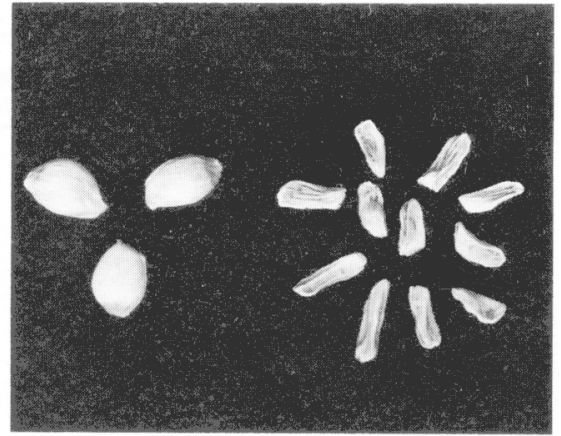

Fig. 1. Normal (left) and undeveloped (right) seeds from mature fruit of $2 \mathrm{x}$ 'Clementinc' $x$ $4 \mathrm{x}$ 'Kawano Natsudaidai'.

The origin of these embryos was verified by determining chromosome number and analyzing the isozyme patterns of plants regenerated from eight polyembryonic seeds having two to 11 embryos. The embryos of these seeds were cultured on Murashige and Tucker (1969) medium containing $500 \mathrm{mg}$ malt extract and $40 \mathrm{mg}$ adenine/liter to induce plantlet formation. Chromosome counts carried out by the root tip squash technique of Oiyama (1981) indicated that all plants produced from any one polyembryonic seed were triploid $(2 \mathrm{n}=3 \mathrm{x}=27)$ (Table 4). Multiple embryos formed in undeveloped seeds are therefore of zygotic origin. Acrylamide gel electrophoretic analysis of peroxidase isozymes according to the method described by Kobayashi (1987) showed no differences in banding patterns among the triploid plants from the same polyembryonic seed (Fig. 3). This similarity suggests that the embryos in one undeveloped seed are
Table 1. Seed set in monoembryonic diploid $x$ tetraploid Citrus crosses.

\begin{tabular}{lccccc}
\hline \hline & & \multicolumn{2}{c}{ No. seeds } & & Undeveloped \\
\cline { 2 - 6 } Seed parent & $\begin{array}{c}\text { No. } \\
\text { fruits }\end{array}$ & $\begin{array}{c}\text { Fully } \\
\text { developed }\end{array}$ & Undeveloped & Total & \begin{tabular}{c} 
Seeds (\%) \\
\hline Clementine
\end{tabular} \\
Mivauchi Ivokan & 20 & 3 & 427 & 430 & 99 \\
& 12 & 24 & 128 & 151 & 85
\end{tabular}

${ }^{z}$ Seed parents were pollinated with $4 \mathrm{x}$ 'Kawano Natsudaidai'.

Table 2. Embryo formation in undeveloped seeds from monoembryonic diploid $\mathrm{x}$ tetraploid Citrus crosses. ${ }^{2}$

\begin{tabular}{|c|c|c|c|c|c|c|c|}
\hline \multirow[b]{3}{*}{ Seed parent } & \multirow{3}{*}{$\begin{array}{l}\text { No. } \\
\text { undeveloped } \\
\text { seeds }\end{array}$} & \multicolumn{6}{|c|}{$\begin{array}{l}\text { Distribution of undeveloped seeds on } \\
\text { the basis of embryo formation }\end{array}$} \\
\hline & & \multicolumn{2}{|c|}{ Monoembryonic } & \multicolumn{2}{|c|}{ Polyembryonic } & \multicolumn{2}{|c|}{ Embryoless } \\
\hline & & No. & $\%$ & No. & $\%$ & No. & $\%$ \\
\hline Clementine & 427 & 248 & 58.1 & 71 & 16.6 & 108 & 25.3 \\
\hline Miyauchi Iyokan & 128 & 71 & 55.5 & 27 & 21.1 & 30 & 23.4 \\
\hline
\end{tabular}

'Seed parents were pollinated with 4x 'Kawano Natsudaidai',

Table 3. Number of embryos in polyembryonic undeveloped seeds from monoembryonic diploid $\mathrm{x}$ tetraoloid Citrus crosses.

\begin{tabular}{lccc}
\hline \hline & $\begin{array}{c}\text { No. } \\
\text { undeveloped } \\
\text { Seed parent }\end{array}$ & seeds & No. embryos/seed \\
\cline { 2 - 4 } Clementine & 40 & $2-17$ & Mcan \pm SD \\
Miyauchi lyokan & 21 & $3-20$ & $4.8 \pm 3.1$ \\
\hline
\end{tabular}

${ }^{\mathrm{z}}$ Seed parents were pollinated with 4x 'Kawano Natsudaidai'. 
Table 4. Chromosome number of regenerated plants from multiple embryos in undeveloped seeds from 2x 'Clementine' crossed with $4 \mathrm{x}$ 'Kawano Natsudaidai'.

\begin{tabular}{lcc}
\hline \multirow{2}{*}{$\begin{array}{l}\text { No. embryos } \\
\text { in examined }\end{array}$} & \multicolumn{2}{c}{ No. regenerated plants } \\
\cline { 2 - 3 } seeds & Chromosome number $(2 \mathrm{n})$ \\
\cline { 2 - 3 } 27 & 2 & Others \\
\hline 2 & 3 & 0 \\
3 & 2 & 0 \\
4 & 3 & 0 \\
5 & 3 & 0 \\
6 & 3 & 0 \\
7 & 4 & 0 \\
8 & 5 & 0 \\
11. & & 0 \\
\hline
\end{tabular}

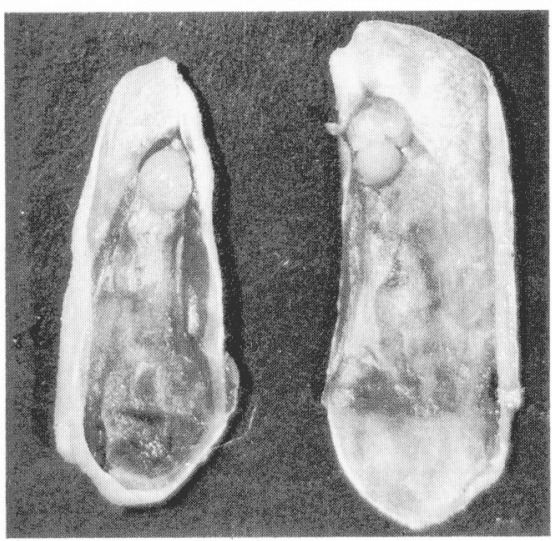

Fig.2. Single (left) and multiple (right) embryos formed in undeveloped seed from $2 x$ 'Clementine' $\times 4 \mathrm{x}$ 'Kawano Natsudaidai'.

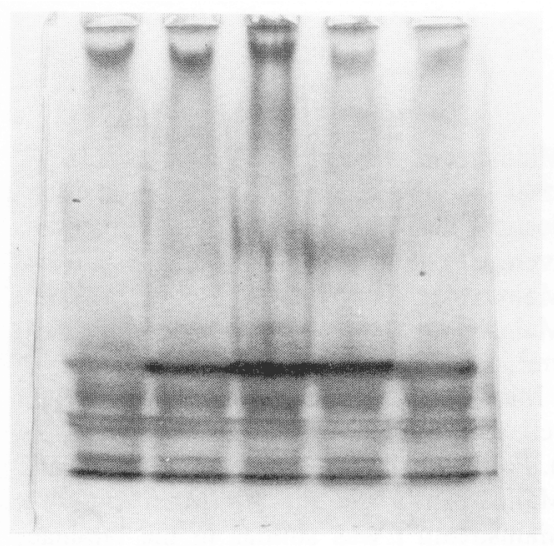

Fig. 3. Isoelectric focusing profiles of peroxidase isozymes in triploid plants produced from one polyembryonic seed.

genetically identical and derived from a single fertilized egg cell.

The present study demonstrates that sexual polyembryony of citrus occurs at the triploid level. This sexual polyembryony seems to be a specific phenomenon related to $a b-$ normal development of triploid embryos in monoernbryonic diploid $\times$ tetraploid crosses.

\section{Literature Cited}

Bacchi, O. 1943. Cytological observations in Citrus. 111. Megasporogenesis, fertilization and polyembryony. Bot. Gaz. 105:221-225.

Cameron, J.W. and M.J. Garber. 1968. Identicaltwin hybrids of Citrus x Poncirus from strictly sexual seed parents. Amer. J. Bot. 55:199-205.
Cameron, J.W. and R.K. Soost. 1969. Characters of new populations of Citrus polyploids, and the relation between tetraploidy in the pollen parent and hybrid progeny. Proc. 1st Intl. Citrus Symp. 1:199-205.

Esen, A. and R.K. Soost. 1972. Tetraploid progenies from $2 \mathrm{x} \times 4 \mathrm{x}$ crosses of Citrus and their origin. J. Amer. Soc. Hort. Sci. 97:410-414.

Esen, A. and R.K. Soost. 1973. Seed development in Citrus with special reference to $2 \mathrm{x} \times$ 4x crosses. Amer. J. Bot. 60:448-462.

Frost, H.B. 1926. Polyembryony, heterozygosis and chimeras in citrus. Hilgardia 1:365-402.

Kobayashi, S. 1987. Uniformity of plants regenerated from orange (Citrus sinensis (L.) Osb.) protoplasts. Theor. Applied Genet. 74:10-14.

Murashige, T. and D.P.H. Tucker. 1969. Growth factor requirements of citrus tissue culture. Proc. 1st Intl. Citrus Symp. 3:1151-1161.

Oiyama, I. 1981. A technique for chromosome observation in root tip cells of citrus. M. Fruit
Tree Res. Sta. D3: 1-7.

Oiyama, L, N. Okudai, and T. Takahara. 1981. Ploidy levels of seedlings obtained from $2 \mathrm{x} \times$ $4 \mathrm{x}$ crosses in citrus. Proc. Intl. Soc. Citriculture 1:32-34.

Ozsan, M. and J. W. Cameron. 1963. Artificial culture of small citrus embryos and evidence against nucellar embryony in highly zygotic varieties. Proc. Amer. Soc. Hort. Sci. 87:210216 .

Parlevliet, J.E. and J.W. Cameron. 1959. Evidence on the inheritance of nucellar embryony in citrus. Proc. Amer. Soc. Hort. Sci. 74:252260.

Tachikawa, T., Y. Tanaka, and S. Hara. 1961. Investigations on the breeding of citrus trees. 1 . Study on the breeding of triploid citrus varieties. Bul. Shizuoka Citrus Expt. Sta. 4:33-44.

Ueno, L, M. Iwamasa, and M. Nishiura. 1967. Embryo number of varieties of citrus and its relatives. Bul. Hort. Res. Sta. B7:11-22. 